\title{
Analysis of Capital Constraints and Influence on the Choice of Rural Households' Entrepreneurial Fields: Evidence from Jiangsu Province in China
}

\author{
Yuan Mo, Shaoda Xu, Junhong Meng* \\ School of Finance, Nanjing University of Finance and Economics, Nanjing, China \\ Email address: \\ junhongmeng@163.com (Junhong Meng) \\ ${ }^{*}$ Corresponding author
}

\section{To cite this article:}

Yuan Mo, Shaoda Xu, Junhong Meng. Analysis of Capital Constraints and Influence on the Choice of Rural Households' Entrepreneurial Fields: Evidence from Jiangsu Province in China. Science Journal of Business and Management. Vol. 6, No. 2, 2018, pp. 45-54.

doi: $10.11648 /$ j.sjbm.20180602.13

Received: May 23, 2018; Accepted: August 3, 2018; Published: August DD, 2018

\begin{abstract}
The "financing difficulty" and "high expense of financing" in rural areas are the main reasons that restrict the development of rural households' entrepreneurship, and the supply-side reform provides an opportunity to improve the rural financial environment. In this paper single variable Probit model is used, Heckman probit model and 1376 Jiangsu micro survey data to analyze the reason of farmers' entrepreneurship. The result shows that the capital constraints exist widely in the entrepreneurship. Different kinds of capital constraints also have different effect on the field choice of farmers' entrepreneurship. Farmers with higher property income and the more formal credit invest more probably in the non-agricultural industry, while farmers with higher formal credit frequency and the identity of creditable household will with high probability engage in the agricultural sector. In addition, the factors such as household's age, political capital, area of cultivated land, and target recognition ability also have a significant impact on the field choice of entrepreneurship. The conclusions can provide implications for the supply-side structural reform of rural financial institutions and the policy-making of supporting entrepreneurship.
\end{abstract}

Keywords: Capital Constraints, Entrepreneurial Choice of Rural Households, Entrepreneurial Fields, Heckman Probit Model

\section{Introduction}

Promoting and supporting farmers' entrepreneurship is an important issue in the era of new normal of economic development and serves as an important method to deepen the agriculture restructure. By the end of 2015, the number of migrant workers who returned home and started their own businesses reached 4.5 million, which is $2 \%$ of all migrant workers1. The businesses they start include scaled farming and breeding, processing of agricultural products, leisure agriculture, rural e-commerce, and many other forms of production and services. Among them new agricultural entities develop very quickly. By May 2017, 870 thousand familiar farms, 1.888 million cooperatives and 386 thousand

1Data from website of central government. agricultural industrialized organizations have registered2. At the same time, phenomenon of farmers' financial constraint on entrepreneurship has attracted researchers' attention. Zuhui Huang and Ning Yu pointed out that collateral requirement, credit process and implicit trade cost and other factors lead to financing difficulty of new agricultural entities [1]. Yajuan $\mathrm{Lu}$ found that family's wealth situation, credit accessibility, and financial resources in the committee are related to farmers' entrepreneurship in the non-agricultural sector [2]. Whether there is significant difference between capital constraints in the agricultural and non-agricultural sectors, and whether this difference will affect farmers' entrepreneurship choice need

2Data from the Department of agriculture. 
further study.

Since 2015, the government has published "Opinions on strengthening promotion services of farmers' innovation and entrepreneurship and promoting farmers' income increase", "Opinions on supporting migrant workers to return home and to start their own businesses", "Guidance on supporting the entrepreneurship and innovation of people return and go to the countryside and promoting the integration of the first, second and third industries in rural areas" and many other documents. In all these documents, banks and financial institutions are promoted to develop financial products and services fit for farmers' entrepreneurship and increase the accessibility of financial services. It is necessary to research on characteristics of farmers' financial demand from the perspective of entrepreneurship. Since 12th Five-Year, 612 thousand farmers have attained entrepreneurial training in Jiangsu Province, 187 thousand farmers have started their businesses, and the number of agricultural leading enterprises above the county level reached $6158^{3}$. The diversification of agricultural entities and the continuous deepening of agricultural industrialization make the entrepreneurial behavior of farmers in Jiangsu very representative. Therefore, this paper sets farmers in Jiangsu Province as research object, and explores the characteristics of capital constraint in the agricultural and non-agricultural sector, and capital constraint's impact on farmers' entrepreneurial behavior, so that theoretical foundation can be made for the design of diversified financial products under the background of the supply-side structural reform of financial institutions.

\section{Literature Review}

After Evans pointed out that capital constraint is obstacle of farmers' entrepreneurship [3], a large number of scholars followed the idea and did in-depth research in this direction. Holtz-Eakin et al. (1994) and Lindh and Ohlsson (1996), used data from the U.S. and Sweden and tested the effect of wealth shocks on self-employment $[4,5]$. However, no consistent conclusion has been reached. One group of researchers think that farmers with more asset will have less capital constraint during their entrepreneurship, so it's more possible for this group of farmers to open up their own businesses. Mingsheng $\mathrm{He}$ and $\mathrm{Xu}$ Shuai (2008) proved that poor farmers' credit demand gap is the largest, credit gap of farmers with high wealth level is the smallest, and the level of household wealth situation is positively related with the possibility of getting enough credit from financial institutions [6]. Potential farmer entrepreneurs may not be able to start their businesses because of credit constraint, and a good financial supporting environment is good for the emergence and development of farmers' entrepreneurship [7, 8]. Financial channels like micro-credit has significantly positive impact on farmer's entrepreneurship and self-employment in China [9]. Huafang Xiao and Xiaolan Bao (2011) researched on this subject further by distinguishing formal and informal financial

3Data from the Jiangsu agriculture website. situation of these farmers' entrepreneurs using Biprobit model and proved that credit rationing policy is the reason of famers' credit constraint [10]. This research finding provides basis for the assumption of dual structure of rural finance used in the empirical part of this paper. Dongliang Cai et al. (2018) used follow-up sample in 2011 and 2013 from 25 provinces in China to analyze the impact of predetermined capital constraint on the entrance of entrepreneurship and got the conclusion that suffering from credit constraint significantly decreases the probability of a household starting their own business in China [11]. Another point of opinion believes that the release of credit constraints cannot raise the number of farmers who choose to start their own businesses. In other words, credit constraint will not affect the entrepreneurship of farmers directly, but land resources and human resources owned by farmers show strong promotion effect on entrepreneurship [12]. So it is necessary to keep land and human resources constant before researching on capital constraint. The researches on capital constraint mentioned above have not distinguished the types of entrepreneurship of farmers. Some researchers have taken the heterogeneity of entrepreneurial behaviors into consideration. For example, Xinzhi Liu and etc. divided the entrepreneurship into "scaled farming of traditional agriculture", "establishment of new industry", "professional production", "offering of new services", and "establishment of new organizations" [13]. Jie Liu and Fengtian Zheng divided the entrepreneurship of farmers into "self-employed entrepreneurship" and "new enterprises" [8]. Yanling Peng and Rong Kong categorized the entrepreneurial states of farmers into "not in the state of entrepreneurship", "entrepreneurship in plan", "continue with entrepreneurship", "stop with entrepreneurship", "restart entrepreneurship" and divided the entrepreneurship motivation into "survival type", "profit-pursuing type" and "type of economic development" [14].

Latest researches focus on the entrepreneurial behavior of new agricultural business entities and their entrepreneurial activities in the industrial and commercial fields. In the agricultural field, new agricultural business entities have strong demand for formal credit. But their lack of qualified collaterals [15], unitarily of financial products offered [16], instability of land lease contracts [17], the complicity of credit application, and high implicit trade costs [1], etc. all these problems lead to financial constraints. Formal credit mainly in the form of micro credits can hardly meet the financial needs of farmers for their production development, and inhibit the long-term investment of farmers. An example is the effect of financial environment and financial knowledge on entrepreneurial behavior of farmers running business of new agricultural technology [18]. In non-agricultural areas, many scholars define farmers' entrepreneurship from the perspective of career switch behavior as self-employment and setup of new enterprises in non-agricultural sector. They find that familiar wealth situation, financial accessibility (like the total amount of credit, formal credit and private lending), and financial resources in the community have positive relationship with choice of entrepreneurship in 
non-agricultural sector [2, 19]. Escobal (2001), for example, finds that access to credit is a significant determinant of non-agricultural self-employment among households in Peru [20].Influenced by the variable "desire for entrepreneurship in the non-agricultural sector", even when normal credit increases remarkably, farmers do not feel relaxation of credit constraint subjectively [21]. It can be concluded that formation of credit constraint in the agricultural and non-agricultural sector is different. Qiaoxin Ping (2012) thinks the difference is resulted from limited responsibility in the agricultural sector and moral hazard in the non-agricultural sector. The more backward the economic development is, the more dominant the limited responsibility in explaining the financial constraint is [22].

Overall speaking, more and more scholars pay attention to the empirical study on capital constraint of entrepreneurship. However, almost no research on the relationship between capital constraint, entrepreneurial behavior and entrepreneurship is undertaken in one unified model. The contribution of this paper lies in the following three aspects. First of all, farmers are divided according to the real situation in the entrepreneurship practice into "not in the state of entrepreneurship", "entrepreneurship in the agricultural sector" and "entrepreneurship in the non-agricultural sector"; secondly, effect of capital constraint on farmers' entrepreneurial behavior is studied, with the focus on its effect on entrepreneurship; thirdly, different from the two-dimensional model used by former researchers, this paper uses Heckman probit two stage model to compare the behavioral differences of entrepreneurship in different sectors and provides one more empirical method for other researches.

\section{Analysis Model}

Career choice theory is based on the assumption that entrepreneurs are rational, and think the precondition of familiar entrepreneurship is that entrepreneurs can obtain more profit through entrepreneurship than wages they otherwise earn as employees. Assume that farmers possess at $t$ period wealth in amount of $\mathrm{m}$, required capital input is $\mathrm{k}$, and the labor input is 1 . farmers can choose to work as employee for others with the wage level of w, or to open up their own businesses. When there is no capital threshold for farmers to start their own businesses $(\mathrm{k} \leq \mathrm{m})$, the output of farmers at $\mathrm{t}$ period is according to Cobb-Douglas function is as follows:

$$
Y=A k^{\alpha} l^{\beta}
$$

A stands for total factor productivity; $\alpha$ and $\beta$ represent the output elasticity of capital and input of labor with the assumption that the scaled rewards keep constant. The opportunity cost of capital is $r$, the average cost of labor is $\omega$, and the total cost of farmers' entrepreneurship can be formulated as follows:

$$
C=r k+\omega l
$$

The net profit of farmers' entrepreneurship:

$$
\pi=A k^{\alpha} l^{\beta}-r k-\omega l
$$

First order condition of the net profit function is:

$$
\frac{\alpha l}{\beta k}=\frac{r}{\omega}
$$

Put (4) into (3), the highest net profit $\llbracket \pi \rrbracket 1^{\wedge *}$ with the optimal combination of production factors is as following:

$$
\pi_{1}^{*}=\left[A\left(\frac{\alpha \omega}{\beta r}\right)^{\beta}-\left(1+\frac{\alpha}{\beta}\right) \omega\right] l
$$

Formal (5) shows that entrepreneurship's net profit is only influenced by total factor productivity and labor, when farmers' wealth is high enough to reach the capital threshold of entrepreneurship. When there are high enough total factor productivity and enough labor input, net profit of entrepreneurship is more than the wage earned as employee, which means $\pi_{1}^{*}>w$. Farmers will choose to start their own business. Migration of rural labor force from rural to urban areas decreases the labor supply in rural areas, supply curve of rural labor force shifts inwards, and the labor cost increases [23]. From the view of cost, entrepreneurships in the agricultural sector are mainly in the form of self-employment. When entrepreneurs have large number of familiar members, they prefer to start business in the agricultural sector, in this way the entrepreneurship cost is the lowest.

For the convenience of statistical check, It is needed to quantify total factor productivity by the means of the following formal:

$$
A=\delta_{0} \sum_{j} X^{\delta_{j}}
$$

is the sum of all factors that influence the entrepreneurship. Since this paper mainly studies the influence of capital constraint on the choice of farmers' entrepreneurship, the factors mentioned in Formal 6 can be simplified into one most relevant factor, namely the situation of financial development in rural areas F. Referring to the formal put forward by King and Levin [24], formal (6) can be simplified into the following one:

$$
A=\delta_{0} F^{\delta_{1}}
$$

Put the representative form of A into formal (5), the highest volume of net profit with optimal input combination can be expressed as followings

$$
\pi_{2}^{*}=\left[\delta_{0} F^{\delta_{1}}\left(\frac{\alpha \omega}{\beta r}\right)^{\beta}-\left(1+\frac{\alpha}{\beta}\right) \omega\right] l
$$

From formal (8), it can be seen that net profit of entrepreneurship is mainly affected by labor and situation of financial development, when the wealth situation of farmers fulfils the requirement of entrepreneurship.

In the case that farmers have capital threshold of entrepreneurship $(k>m)$, imagine that $1-\lambda$ of credit requirement of farmers can be satisfied. When the credit applied by farmers is credit against collateral with fixed asset 
$\mathrm{X}$ as the qualified collateral. $\mathrm{X}$ is equal to tm. The highest level of farmers' capital input equals $(1-\lambda) X+m$. Since the realistic capital input $\mathrm{k}$ is less or equal to $(\mathrm{t}-\mathrm{t} \lambda-1) \mathrm{m}$, the highest capital $\mathrm{k}=(\mathrm{t}-\mathrm{t} \lambda-1) \mathrm{m}$ under capital constraint can be put into formal (3) and get:

$$
\pi(m)=\left[\frac{\delta_{0} F^{\delta_{1}}}{(\alpha \omega)^{\beta}}-\left(r+\frac{1}{\alpha}\right)\right](t-t \lambda-1) m
$$

Farmers' entrepreneurship choice is affected mainly by financial development, credit fulfillment, value of collateral and wealth situation of farmers' family. If $m$ is larger than $\mathrm{k} \_$min and $\pi(\mathrm{m})$ is larger than $\mathrm{w}$, then farmers will possibly choose to start their own businesses. Entrepreneurship in the agricultural and non-agricultural sector has different capital constraint, investment feature and familiar endowment. Different situation of capital constraints will affect farmers' choice of entrepreneurship fields. The way and degree of their effect need further verification.

\section{Data Resource and Depictive Statistics}

\subsection{Data Resource}

Referring to the definition of farmers' entrepreneurship of former researchers [19], farmers' entrepreneurship is confined to scale management through employing family members and establishment of new organizations in the agricultural and non-agricultural sectors. Entrepreneurs in the agricultural sector include big producers of farming, forestry, animal husbandry, side-line production and fishery, big producer of agricultural processing, big provider of agricultural machines, big provider of plant protection services, big seller, broker of agricultural products, and operator of professional farmers' cooperatives, founder of workshops, factories and enterprises in agriculture-related industries and services. The entrepreneurship in the non-agricultural sector refers to privately or individually-owned business in the non-agricultural sector, or factories and enterprises in the non-agricultural sector.

Table 1. Individual and familiar characteristics of sample farmers.

\begin{tabular}{|c|c|c|c|}
\hline Index & Categories & Sample number & Proportion \\
\hline \multirow{2}{*}{ Gender } & male & 1105 & $80.31 \%$ \\
\hline & female & 271 & $19.69 \%$ \\
\hline \multirow{4}{*}{ Age } & Under 35 & 221 & $16.06 \%$ \\
\hline & $35 \sim 45$ & 445 & $32.34 \%$ \\
\hline & $45 \sim 55$ & 555 & $40.33 \%$ \\
\hline & Above 55 & 155 & $11.26 \%$ \\
\hline \multirow{3}{*}{ Education } & Less than 6 years & 304 & $22.09 \%$ \\
\hline & $6-9$ years & 581 & $42.22 \%$ \\
\hline & Over 9 years & 491 & $35.68 \%$ \\
\hline \multirow{3}{*}{ Number of family members } & Equal or less than 3 & 341 & $24.78 \%$ \\
\hline & $4 \sim 5$ & 771 & $56.03 \%$ \\
\hline & 6 and over 6 & 264 & $19.19 \%$ \\
\hline \multirow{2}{*}{ Familiar average income } & 20000 Yuan and less than 20000 Yuan & 612 & $44.48 \%$ \\
\hline & Above 20000 Yuan & 764 & $55.52 \%$ \\
\hline
\end{tabular}

The data used in this paper is from the survey of rural finance undertaken by our research group in 2016. The content of questionnaires include information about family wealth situation, characteristics of decision-maker, lending behavior, and entrepreneurship characteristics, etc. Except incomplete and untruthful questionnaires 1376 questionnaires were collected from 13 prefecture-level cities. $92 \%$ of the questionnaires are valid. 415 questionnaires are from the southern part of Jiangsu Province, which make up 30.16\% of all questionnaires; 378 questionnaires are from central part of Jiangsu Province, which account for $27.47 \%$ of all questionnaires; 583 questionnaires are from the northern part of Jiangsu Province and they make up $42.37 \%$ of all questionnaires. Among the surveyed farmers, $46 \%$ or 633 farmers start their own businesses. 192 opened their businesses in the agricultural sector and 441 in the non-agricultural sector. According to table 1, a large part of the surveyed farmers are middle-aged and elderly people with the average age $45.1 .72 .67 \%$ of sample farmers are in the range of 35 and 55 years old. Most of surveyed farmers have the education background of junior middle school, which makes up $42.22 \%$ of all surveyed farmers. The farmers with high school education background or higher education level accounts for $35.68 \%$ of all surveyed farmers. The number of family member concentrates mainly on the range 4-5 people. $56.03 \%$ of surveyed farmers are in this category. Median of average family income is 20000 Yuan. The distribution of sample farmers is basically in line with normal distribution, which satisfies the research requirement.

\subsection{Depictive Statistics}

(1) Familiar wealth situation. This paper studies farmers' internal capital constraint from the perspective of business earnings, wage income, property income, fixed assets and cultivated land area. First of all, table 2 shows that the mean value and standard deviation of entrepreneurs' family wealth are higher than non-entrepreneurs, which proves that wealth accumulation helps farmers realize career change. But the risk of entrepreneurship also increases the fluctuation of family wealth. Entrepreneurs have to bear more risk. Secondly, the more business profit, wage income, property income and fixed assets famers earn and possess, the more possible that they choose to start business in the non-agricultural sector. Under the background of industrial upgrading in rural areas and inclusive finance, farmers' property wealth is mainly resourced from transfer of contracted land management right, 
transfer of rural collective property to shares and appreciation of farmers' real-estate and rural homestead. 520 sample farmers have property income, which make up $37.79 \%$ of all surveyed farmers. Among them 260 households are entrepreneurs, which make up $41.07 \%$ of all sample entrepreneurs. Fixed assets in this paper include family living house and fixed assets for production. Although family living house of rural households is seldom regarded as qualified collateral by financial institutions. But house value is positively related to lending ability of family [9]. After the central government published "Interim measures for the pilot of housing property mortgage loans for farmers" in 2016, lands and houses in rural areas have gradually been accepted as important asset items by financial institution. The average land area of entrepreneurs in the agricultural sector is significantly larger than entrepreneurs in non-agricultural sector. This proves that the land circulation policy works and contributes to scaled farming of new agricultural entities.

Table 2. Comparison of wealth accumulation of rural households.

\begin{tabular}{llll}
\hline \multirow{2}{*}{ Index } & Non-entrepreneur & Entrepreneurs & \\
\cline { 3 - 4 } & farmers & All entrepreneurs & $\begin{array}{l}\text { Entrepreneurs in the } \\
\text { agricultural sector }\end{array}$ \\
& & $\begin{array}{l}\text { Entrepreneurs in the } \\
\text { non-agricultural sector }\end{array}$ \\
\hline Business and wage income (thousand Yuan) & $93(86)$ & $220.3(810.3)$ & $155.8(136.7)$ \\
Property income (thousand Yuan) & $3.7(10.5)$ & $12.5(56.6)$ & $3.9(8.8)$ \\
Fixed assets for production (thousand Yuan) & $18.6(139.0)$ & $174.1(1123.2)$ & $51.1(123.1)$ \\
Value of houses (thousand Yuan) & $317.9(456.8)$ & $496.5(840.6)$ & $369.2(473.8)$ \\
Area of cultivated land (mu) & $41.6(72.5)$ & $57.0(181.2)$ & $96.4(284.2)$ \\
\hline
\end{tabular}

Note: value in brackets is standard deviation.

(2) Capital constraint. To further investigate the capital constraint situation of farmers, table 3 lists farmers' detailed financing situation. First of all, entrepreneurs' valid credit demand is stronger than that of non-entrepreneurs. 488 farmers in the sample have ever applied for credits, among them 345 are entrepreneurs $(70.70 \%)$, and the other 143 are non-entrepreneurs $(29.30 \%)$. The financing volume of entrepreneurs accounts for $83 \%$ of the total credit amount. Secondly, the average credit volume of each credit is used to reflect farmers' lending ability. The formal credit lending ability of entrepreneurs in the agricultural sector is weaker than that of entrepreneurs in the non-agricultural sector, but they show stronger lending ability from informal channel. The reason for that is agricultural production has strong seasonal feature and this feature ensures regular and stable repayment of credit according to production circle. So entrepreneurs in the agricultural sector can obtain credit with relatively high volume from informal channel. But character of low profitability of agricultural production lowers the possibility of them to obtain credit from formal channel. Thirdly, whether entrepreneurs' financing demand can be satisfied, is also related to capital cost. According to our statistical data, average monthly interest of informal credit is higher than that of formal credit. This can be interpreted as the result from information asymmetry in the informal lending, it is also a premium required by the credit supplier for providing convenient and flexible financial services. Monthly interest rate of credit for entrepreneurs in the agricultural sector is higher than that for entrepreneurs in the non-agricultural sector. This is probably because of high risk in the agricultural sector recognized by financial institutions. Because of the limit of resource, technology and information in the agricultural sector, farmers in this sector face more risk, so the entrepreneurship in the agricultural sector is riskier. When the sample without interest-free credit from friends and relatives is compared with the sample with interest-free credit from friends and relatives, it shows that lending from friends and relatives contribute significantly to the reduction of entrepreneurship's financing cost. This reflects the sensitivity of entrepreneurs to capital cost and the importance of social resources. In comparison with formal credit, informal credit has advantages in transferring soft information.

Table 3. Statistical data of farmers'financing situation.

\begin{tabular}{lllll}
\hline \multirow{2}{*}{ Type of farmers } & \multicolumn{2}{l}{ Credit (number of credits) } & \multicolumn{2}{l}{ Financing amount (10 thousand Yuan/each credit) } \\
\cline { 2 - 5 } & Formal credit & Informal channel & Formal channel & Informal channel \\
\hline Non-entrepreneurs & 83 & 60 & $13.64(15.49)$ & $3.45(4.52)$ \\
entrepreneurs & 241 & 104 & $24.41(45.90)$ & $8.80(15.89)$ \\
In the agricultural sector & 90 & 38 & $11.90(23.89)$ & $7.59(18.04)$ \\
In the non-agricultural sector & 152 & 65 & $30.86(52.77)$ & $9.49(14.67)$ \\
\hline
\end{tabular}

Table 3. Continued.

\begin{tabular}{llll}
\hline \multirow{2}{*}{ Type of farmers } & \multicolumn{3}{c}{ Average monthly interest rate (\%) } \\
\cline { 2 - 4 } & Formal channel & Informal channel (without interest-free sample) & Informal channel (including interest-free sample) \\
\hline Non-entrepreneurs & $0.60(0.49)$ & $0.86(0.50)$ & $0.13(0.36)$ \\
entrepreneurs & $0.75(0.41)$ & $1.13(1.70)$ & $0.45(1.20)$ \\
In the agricultural sector & $0.88(0.50)$ & $1.43(2.60)$ & $0.64(1.85)$ \\
In the non-agricultural sector & $0.68(0.34)$ & $0.92(0.60)$ & $0.34(0.58)$ \\
\hline
\end{tabular}




\section{Model Construction and Empirical Test}

\subsection{Model Construction}

According to the existing literature, the model used to investigate the entrepreneurship choice behavior of farmers is two-dimensional choice model Probit model. Refering to Xichuan Liu, etc [25], since nonrandom sample can lead to biases in the empirical result, non-entrepreneurs may also have credit demand, which will restrict the dependent variable Heckman two-stage model can be used to avoid problems mentioned. This paper uses Heckman probit model to solve the problem of biases because of nonrandom sample. Concrete procedure is as follows: the analysis of entrepreneurship choice behavior is divided into two parts. The first part is the construction of function to depict whether farmers will start their own businesses. Probit model is used to analyze the factors that can affect farmers' entrepreneurship choice behavior. In the second part the construction function to depict the entrepreneurship field choice is established. Probit model is used further to analyze the influence factors of field choice of entrepreneurs using the data of entrepreneur sample. Some factors may affect farmers' entrepreneurship decision, but may not affect the field they choose or to say may not affect whether farmers will start their businesses in the agricultural sector. Combined with the aim of the paper, namely capital constraint, the following models are used:

$$
\begin{gathered}
\mathrm{P}\left(W_{i}=1 \mid X_{i}\right)=\alpha_{0}+\sum_{i=1} \alpha_{i} X_{i}+\mu_{i} \\
\mathrm{P}\left(Z_{i}=1 \mid Y_{i}\right)=\beta_{0}+\sum_{i=1} \beta_{i} Y_{i}+\varepsilon_{i}
\end{gathered}
$$

$W_{i}$ is farmers' entrepreneurship choice. $W_{i}=1$ means that farmers choose to start their own businesses. $W_{i}=0$ stands for non-entrepreneurship. $\mathrm{P}_{i}$ measures the probability of entrepreneurship. $X_{i}$ represents main influence factors for the choice of entrepreneurship. $\alpha_{i}$ is the coefficient of relevant variables. $\mu_{i}$ is stochastic disturbance term; $Z_{i}$ describes the choice of entrepreneurship field. $Z_{i}=1$ stands for the entrepreneurship in the agricultural sector. $Z_{i}=0$ means choice of entrepreneurship in the non-agricultural sector. $Y_{i}$ stands for main influence factors that affect the choice of entrepreneurship fields. $\beta_{i}$ is the coefficient of relevant variables. $\varepsilon_{i}$ is stochastic disturbance term. The set of variables is described in table 4 .

\begin{tabular}{|c|c|c|c|c|}
\hline & Definition of variables & $\begin{array}{l}\text { Sample } \\
\text { amount }\end{array}$ & $\begin{array}{l}\text { Mean } \\
\text { value }\end{array}$ & $\begin{array}{l}\text { Standard } \\
\text { deviation }\end{array}$ \\
\hline \multirow{4}{*}{$\begin{array}{l}\text { Dependent } \\
\text { variables }\end{array}$} & Entrepreneurship choice ( $1=$ entrepreneurship; $0=$ non-entrepreneurship) & 1376 & 0.46 & 0.50 \\
\hline & Entrepreneurship fields $(1=$ agricultural sector; $0=$ non-agricultural sector $)$ & 633 & 0.30 & 0.46 \\
\hline & Credit amount (average credit amount per credit, unit: 10000 Yuan/each credit) & 391 & 16.05 & 33.28 \\
\hline & Lending frequency (times of credit in the last two years) & 391 & 1.25 & 0.56 \\
\hline \multirow[t]{8}{*}{ Capital constraint } & Distance to financial institutions (distance to the nearest bank, unit: km) & 1376 & 3.32 & 3.77 \\
\hline & Number of financial institutions (Number of financial institutions in the village and town) & 1376 & 4.59 & 3.94 \\
\hline & Gender $(1=$ male, $0=$ female $)$ & 1376 & 0.80 & 0.40 \\
\hline & Age (unit: year old) & 1376 & 45.07 & 9.15 \\
\hline & Years of education (unit: year) & 1376 & 9.07 & 3.26 \\
\hline & Number of labor force (labor force in the family, unit: person) & 1376 & 2.58 & 1.08 \\
\hline & Rate of familiar burden (percentage of family members need to be taken care of, unit:\%) & 1376 & 0.97 & 0.83 \\
\hline & Area of cultivated land (unit: mu) & 1376 & 4.87 & 13.41 \\
\hline \multirow{7}{*}{$\begin{array}{l}\text { Feature of } \\
\text { individuals and } \\
\text { households }\end{array}$} & $\begin{array}{l}\text { Attitude to risk: risk preference (designed question: if your monthly salary is } 2800 \text { Yuan, you can } \\
\text { change your job with the probability of } 50 \% \text { to earn } 5600 \text { Yuan or noting, would you choose to } \\
\text { change your job? When answer is to keep the first job, means prefer risk) }\end{array}$ & 1376 & 0.23 & 0.42 \\
\hline & & 1376 & 0.48 & 0.50 \\
\hline & Risk control ability ( $1=$ purchase of commercial insurance; $0=$ no purchase of commercial insurance) & 1376 & 0.52 & 0.50 \\
\hline & $\begin{array}{l}\text { Entrepreneurial spirit (designed question: if you win the lottery and earn } 1 \text { million Yuan, will you } \\
\text { choose to retire? } 1=\text { no, } 2=\text { yes, I will retire. The one chooses } 1 \text { has entrepreneurial spirit.) }\end{array}$ & 1376 & 0.70 & 0.46 \\
\hline & $\begin{array}{l}\text { Chance recognition: ( designed question: if you plan to start your business, do you possess enough } \\
\text { resource or can you obtain resources from other people? } 1=\text { method recognition, } 0=\text { not sure) }\end{array}$ & 633 & 0.67 & 0.47 \\
\hline & $\begin{array}{l}\text { Risk recognition: (designed question: do you know what business you want to run, } 1=\text { aim } \\
\text { recognition, } 0=\text { not sure) }\end{array}$ & 633 & 0.86 & 0.35 \\
\hline & Are you a creditable household? $(1=$ yes, $0=$ no $)$ & 1376 & 0.40 & 0.49 \\
\hline \multirow[t]{2}{*}{ Social resources } & Are you a member of the Communist Party of China? $(1=$ yes, $0=$ no $)$ & 1376 & 0.11 & 0.31 \\
\hline & Are you a village cadre? $(1=$ yes, $0=$ no $)$ & 1376 & 0.07 & 0.25 \\
\hline
\end{tabular}

Table 4. Depictive statistics of relevant variables.

\subsection{Empirical Result}

This paper uses Stata 12.0 and Heckman probit model to analyze farmers' entrepreneurship choice. Combined with the feature of dual structure of rural finance, empirical model is used to check the capital constraint in formal and informal financial channel respectively. Whether farmers will choose to start their businesses, depends on the revenue and cost of entrepreneurship. In the Heckman probit model, capital constraint, individual and familiar feature, and social 
resources as explanatory variables are chosen and the influence factors of farmers' entrepreneurship choice are analyzed. In the test of entrepreneurship field choice, the focus is the influence of capital constraint, feature of rural householder, social resources and chance recognition ability on farmers' choice of entrepreneurship fields. From the result of table 5 it can be seen that likelihood ratio test in the Heckman probit model is passed at a higher level of significance, which proves that the division of entrepreneurship into two parts is a right decision. The direction of coefficients in the single variable Probit test and Heckman probit test is almost the same, which proves the stability of estimation result of Heckman probit model. Since the estimation result of Heckman probit model is more valid, the following discussion is based on the result of Heckman probit model.

Table 5. Empirical result of entrepreneurship choice and field choice.

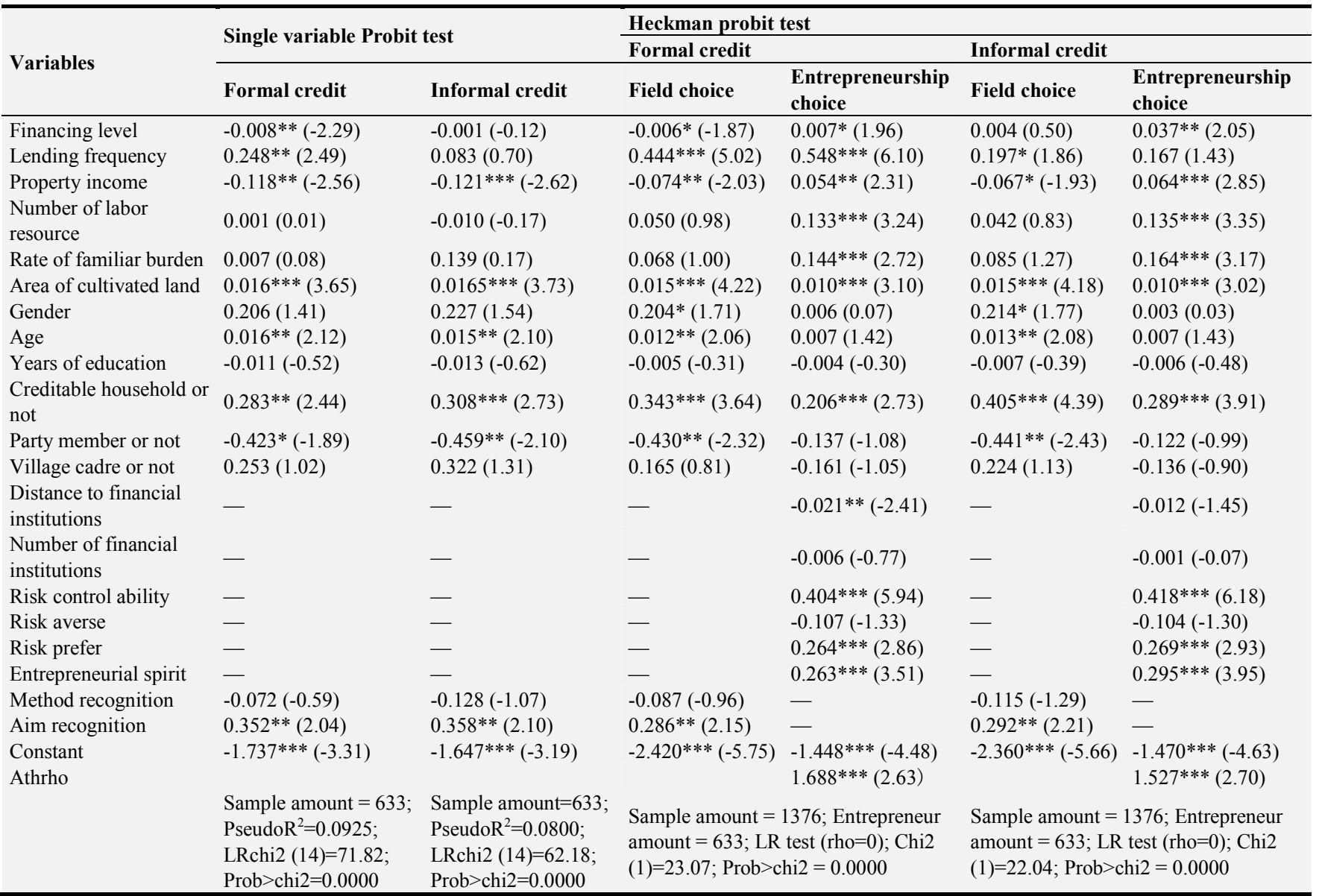

Note: $(1) * * *, * * *$ corresponding to a $10 \%, 5 \%, 1 \%$ significance level, value in brackets in Z value; (1) Formal credit function is base function and informal credit function is contrast function.

The estimation results shows that the entrepreneurship choice is influenced both by capital endowment of farmers' family and their entrepreneurial ability. First of all, capital constraint restricts farmers' entrepreneurship choice significantly. From the perspective of internal capital constraint, the more income family earns, the more probably farmers choose to start their own businesses, and the more motivated they are to engage in the non-agricultural sector. There are scholars who have proved the existence of farmers' credit constraint and the negative relationship between credit constraint and income [26]. To solve possible endogenous problem, the "property income" as proxy variable to replace the variable household income is used.

From the perspective of external capital constraint, financing level affects the entrepreneurship choice positively, formal credit constraint also restricts fields and level of farmers' entrepreneurship. For example, entrepreneurship in the non-agricultural sector faces high threshold, the approval procedure is complicated and the capital demand in this sector is stronger. The coefficient of lending frequency of formal credit is significantly positive in deciding whether to start business or not and in deciding whether the business is in the agricultural sector. Farmers who often lend from banks will probably start their own business, because they can easily obtain loans from financial institutions. The more formal credits farmers obtain, the less collateral and guarantee banks require because of the establishment of trust mechanism between farmers and financial institutions [27]. When there is lack of qualified collateral, good creditability of farmers will relax capital constraint. Since farmers can only obtain loans in small amount, and credit for the agricultural sector has the feature of high frequency and seasonality. Only through 
repeated use of loans, financial demand of big farmers can be satisfied, so farmers who have usually lent from banks will probably choose to start their own business in the agricultural sector. This result is also proven by the empirical result. But small-scaled loans, high frequency of lending and short lending term will increase the management difficulty of banks and make the banks limit their lending activities. The coefficient of variable "distance between banks and farmers" in the entrepreneurship choice model is statistically significant at the $5 \%$ level, and the value is negative. This proves that the nearer the banks lie, the more information farmers receive and more probably farmers will start their own business. The coefficient of the variable number of financial institutions is in the function not significant.

Secondly, opportunities and risks exist in farmers' entrepreneurship at the same time. Having the spirit of adventure is the precondition for entrepreneurship choice. Jiangxia $\mathrm{Hu}$ and Chuanhao Wen find through their survey on farmers' migration that there are positive relationship between farmers' risk recognition ability and sustainable development [28]. According to table 5, risk-preference and risk control ability increase farmers' entrepreneurship motivation at the significant level $1 \%$. The coefficient of risk-adverse is negative, but it did not pass the significance test. The difference between risk-preference and blind adventure is the ability of farmers to recognize entrepreneurship opportunity. Risk-preference and entrepreneurial ability to evaluate farmers' entrepreneurial behavior should be combined. Entrepreneurial spirit is at level $1 \%$ significant and the value of its coefficient is positive. The number of entrepreneurs with entrepreneurial spirit is $14.58 \%$ higher than the number of non-entrepreneurs with entrepreneurial spirit, the number of entrepreneurs with this spirit in the non-agricultural sector is $10.42 \%$ higher than that in the agricultural sector. In the entrepreneurship field choice function, aim recognition is at the level 5\% significant and the value of coefficient is positive. Method recognition is not significant. It shows that farmers who have long-term experience in agricultural production or successful experience in this field are more willing to choose a business in the field of agriculture. It is because of the lack of farmers' understanding of the non-agricultural industry. If the government can carry out the popularization of industry knowledge and provide training of professional skills, the non-agricultural upgrading of the rural industry can be promoted to some extent.

Thirdly, social resources also affect the willingness and behavior of farmers' entrepreneurship. The identity of creditable household is in both the entrepreneurship choice function and field choice function at the level of $1 \%$ significant and coefficient is positive. Since the rural commercial banks in Jiangsu Province launched credit rating activity "creditable users and creditable villages", formal micro credit is more and more important in promoting agricultural industrialization. The identity of party members and village cadres as farmers' political capital reflects farmers' social status and social network to some extent, and it is also a reflection of farmers' reputation in the local area. In general, information acquisition and social communication will have an impact on entrepreneurial performance through social capital accumulation [29]. These two variables are not significant in the entrepreneurship choice function, but the identity of party member is significantly negative in the entrepreneurial field choice function, which indicates that the role of party members is more prominent in non-agricultural industry upgrading than that in the agricultural field.

Finally, other characteristic variables of individual and family also have an impact on the behavior of farmers' entrepreneurial choice. The number of household labor and the population burden rate will affect the choice of whether entrepreneurs employ labor force. The more abundant labor a family possesses, the stronger they are motivated to start business of "opportunity type entrepreneurship"; the heavier the population burden is, the stronger the motivation of starting business of the "survival type entrepreneurship" is. The coefficient of demographic characteristics is positive in the field choice function, but not significant. The cultivated land area of the family significantly improved the farmers' willingness to start a business in the field of agriculture. According to statistics of the Ministry of Land and Resources, Jiangsu province carried out the ownership registration of rural contracted land management rights since 2015. As of 20163095 acres of land have realized transfer of contracted land management right, which is $60 \%$ of all contracted lands. This initiative directly promoted the scaled management of agriculture and establishment of new agricultural business entities in Jiangsu.

The current land reform policy that allows the use of land management right as collateral has effectively alleviated the liquidity constraints of the farmers. The age is significant and positive in the field choice function. The sample shows that entrepreneurs in the agricultural sector are 2.13 years older than entrepreneurs in the non-agricultural sector in average. This reflects the new agricultural subjects in Jiangsu province are in the trend of aging, there will be not enough successors in agricultural production.

\section{Conclusion and Illusion}

Based on the theory of static career choice, this paper deepens the relationship research between capital constraint and farmers' entrepreneurial choice behavior. Using the 1376 household survey data of Jiangsu Province in 2015, this article focuses on the impact mechanism of capital constraints on the different choice of farmers' entrepreneurial field. Combined with descriptive statistics and empirical models, the following conclusions can been drawn: (1) the higher the family wealth level is, the more probably farmers participate in entrepreneurship, which indicates that farmers' entrepreneurial financing constraints are widespread. Family property income helps to improve the probability of farmers' participation in non-agricultural entrepreneurship. (2) Formal credit constraints inhibit farmers' entrepreneurial willingness. The higher the level of farmers' financing is, the more probably farmers participate in entrepreneurship in the 
non-agricultural areas; the higher the formal loan frequency is, the more probably farmers start their businesses in the agricultural sector; the closer banks are, the higher the probability of entrepreneurship is. (3) Farmers who have the spirit of adventure and the ability to recognize the opportunity are more likely to achieve career transformation. Compared to the non-agricultural field, it is easier to identify the purpose of agricultural entrepreneurship, which helps to improve the probability of farmers' participation in entrepreneurship in the agricultural sector. (4) Under the background of aging of population, the number of family labor and population burden rate will affect farmers' entrepreneurial choice. Compared with young farmers, senior farmers will be more probable to participate in entrepreneurship in agriculture.

According to the above conclusions, the following illusions can be drawn: first, we should insist on improving the market mechanism of transfer and trade of contracted land management right, improving farmers' property income level and promoting mortgage loan pilot against rural land management right. Increase of the credit availability of farmers will promote farmers' entrepreneurship and innovation in a certain extent. Second, with the help of the structural transformation on the supply side, financial institutions should provide financial products and services that match the needs of different farmers. Banks should optimize business process, increase the credit amount, and strengthen the supervision after the loan. For large loan businesses with large volume and long cycle, a risk sharing mechanism can be established, for example, through the bank insurance cooperation mode, the loan risk can be reduced and the career safety can be secured that farmers may have in the process of agricultural conversion, and ultimately achieve the upgrading of farmers' entrepreneurial level. Third, improve the financial environment. Continue to promote "creditable households" and "creditable village" project, provide a good credit environment in order to better identify potential entrepreneurial farmers; Use Internet finance to break the geographical distance constraints, adhere to the technology driven, promote the development of digital inclusive financial, and change the high cost situation of rural financial operation. Fourth, cultivate and develop new agricultural management entities, alleviate the contradiction between the talent demand of agricultural industrialization and the shortage of new farmers. Guidance and training service system of entrepreneurship should be established and improved, farmers' cognitive level and information acquisition ability should be improved, so that they could identify entrepreneurial opportunities more sharply and industrial upgrading can be achieved.

\section{References}

[1] Huang, Zuhui and Yu, Ning. New rural business entities of agricultural sector: status quo, constraints and development root - a case study of Zhejiang Province [J]. Chinese rural economy, 2010 (10), pp. 16-26.
[2] Lu, Yajuan, Zhang, Longyao and $\mathrm{Xu}$, Yuyun. Access to finance and rural household entrepreneurship - an empirical study based on CHARLS data [J]. Economic theory and business management, 2014 (10), pp. 89-99.

[3] Evans D S, Jovanovic B. An estimated model of entrepreneurial choice under liquidity constraints [J]. Journal of political economy, 1989, 97 (4), pp. 808-827.

[4] Holtz-Eakin, D., and Rosen, H. Entrepreneurial decisions and liquidity constraints [J]. RAND Journal of Economics, 1994 (25-2), pp. 334-337.

[5] Lindh, T., and Ohlsson, H. Self-employment and windfall gains: Evidence from the Swedish Lottery [J]. Economic Journal, 1996 (106-439), pp. 1515-1526.

[6] He, Mingsheng and Shuai, Xu. Study on farmers' credit demand and credit gap under financial constraint [J]. Journal of financial research, 2008 (7), pp. 66-79.

[7] Bianchi M. Credit constraint, entrepreneurial talent and economic development [J]. Small business economic, 2010, 34, pp. 93-104.

[8] Jia, Xiangping, Xiang, Cheng and Huang, hukun. Microfinance, self-employment, and entrepreneurs in less developed areas of rural China [J]. China economic review, 2013 (27), pp. 94-103.

[9] Liu, Jie and Zheng, Fengtian. Liquidity constraint on entrepreneurial choice behavior of peasant households: based on survey of 894 families in Shanxi, Gansu and Zhejiang Provinces [J]. Finance and trade research, 2011 (3), pp. 28-35.

[10] Xiao, Huafang, Bao, Xiaolan. Credit constraint on farmers' entrepreneurship - empirical study based on 930 micro enterprises in Hubei Province [J]. Journal of agrotechnical economics. 2011 (2), pp. 102-109.

[11] Dongliang Cai, Quanyun Song, Shuang Mab, Yang Dong, Qiuhua Xu. The relationship between credit constraints and household entrepreneurship in China International [J]. Review of Economics and Finance. 2017, http://dx.doi.org/10.1016/j.iref.2018.03.024.

[12] Cheng, Yu and Luo, Dan. Farmers' entrepreneurship choice behavior under credit constraint - empirical study based on survey of Chinese farmers [J]. Chinese rural economy, 2009 (11), pp. 25-38.

[13] Liu, Xinzhi, Liu, Yusong and Li, Lu. A study on the impact of entrepreneurial environment on farmers' behavior of starting businesses [J]. Journal of Southwest University (natural science edition), 2015 (4), pp. 1-8.

[14] Peng, Yanling and Kong, Rong. Study on collateral of contracted land management right, liquidity constraint and farmers' different choice of entrepreneurship fields [J]. Journal of agrotechnical economics, 2016 (5), pp50-59.

[15] Lv, Huiming and Zhu, Yuxuan. Study on development model of family farms based on survey - a case study of Ningbo City of Zhengjiang Province [J]. Issues in agricultural economy, 2015 (4), pp. 19-26.

[16] Liu, Tingting. Financing difficulty of new agricultural business entities and the reform path of financial support for agriculture [J]. Rural economy, 2016 (3), pp. 73-77.

[17] Cui, Ningbo and Song, Xiujuan. Status quo and further study of new agricultural business entities - a case study of Harbin City. [J]. Journal of Northeast Agricultural University (Social science edition), 2015 (3), pp. 19-25. 
[18] Zheng, Baohua and Lu, Yumei. Research on the impact of entrepreneurship environment in the agriculture technology park on entrepreneur behavior [J]. Journal of agrotechnical economics, 2016 (11), pp. 115-122.

[19] Yang, Jun, Zhang, Longyao and Jiang, Yan. Study on social financial resource, family financing and farmers' entrepreneurship based on CHARLS survey data [J]. Journal of agrotechnical economics, 2013 (11), pp. 71-79.

[20] Escobal, J. The determinants of nonfarm income diversification in rural Peru [J]. World Development, 2001 (29-3), pp. 497-508.

[21] Peng, Keqiang and Liu, Xiliang. Increase of farmers' income, accessibility of formal credit and non-agricultural entrepreneurship [J]. Management world, 2016 (7), pp. 88-97.

[22] Ping, Xinqiao, Zhang, Haiyang, Hao, Chaoyan and Liang, Shuang. Study on the formation of farmers' financial constraint [J]. Economics information, 2012 (4), pp. 10-14.

[23] Zhong, Funing. Correct understanding of food security and the cost of agricultural labor [J]. Issues in agricultural economy, 2016 (1), pp. 4-9.
[24] King RG, Levine R. Finance, entrepreneurship and growth [J]. Journal of monetary economics, 1993 (32), pp. 513-542.

[25] Liu, Xichuan, Chen, Lihui and Yang, Qiming. Relationship between farmers' formal credit demand and interest rate: based on empirical study using TobitIII model [J]. Management world, 2014 (3), pp. 75-91.

[26] Wang, Shuhua, Yang, Youzhen and Su, Jian. The dynamic impact mechanism of farmers' credit constraint and income gap: based on estimation of the panel joint system [J]. Economic survey, 2014 (1), pp. 26-31.

[27] Behr P,. Entzian A, Guttler. How do lending relationships affect access to credit and loan conditions in micro lending [J]. Journal of banking and finance, 2011 (35), pp. 2169-2178.

[28] Hu, Jiangxia and Wen, Chuanhao. The relationship between social network, risk recognition ability and sustainable livelihood of migrant workers [J]. Technology economics, 2017 (4), pp. 110-116.

[29] Yang, Delin, $\mathrm{Hu}, \mathrm{Xiao}$ and Feng, Ya. Internet application and entrepreneurship performance: the intermediary role of social capital [J]. Technology economics, 2017 (4), pp. 53-62. 